\title{
COVID-19 IMPACT ON STUDENTS
}

\author{
Andria Pragholapati \\ Department of Nursing, Faculty of Sport Education and Health, Universitas Pendidikan Indonesia, \\ Bandung, Indonesia
}

E-mail: andria.pragholapati@upi.edu

\section{Introduction}

As we have questioned today in the world, especially Indonesia which is struggling against Coronavirus or commonly known by the name (COVID-19), which is already much needed by victims. Coronavirus or commonly known by the name (COVID-19) is an infectious disease caused by a newly discovered coronavirus [1]. Total global COVID-19 confirmation cases as of May 6, 2020 are 3,517,345 cases with 243,401 deaths (CFR 6.9\%) in 214 Contracted Countries. Data in Indonesia as of May 6, 2020 confirmed 12,438 verified 9,226 received 895 and recovered 2,317 [2]

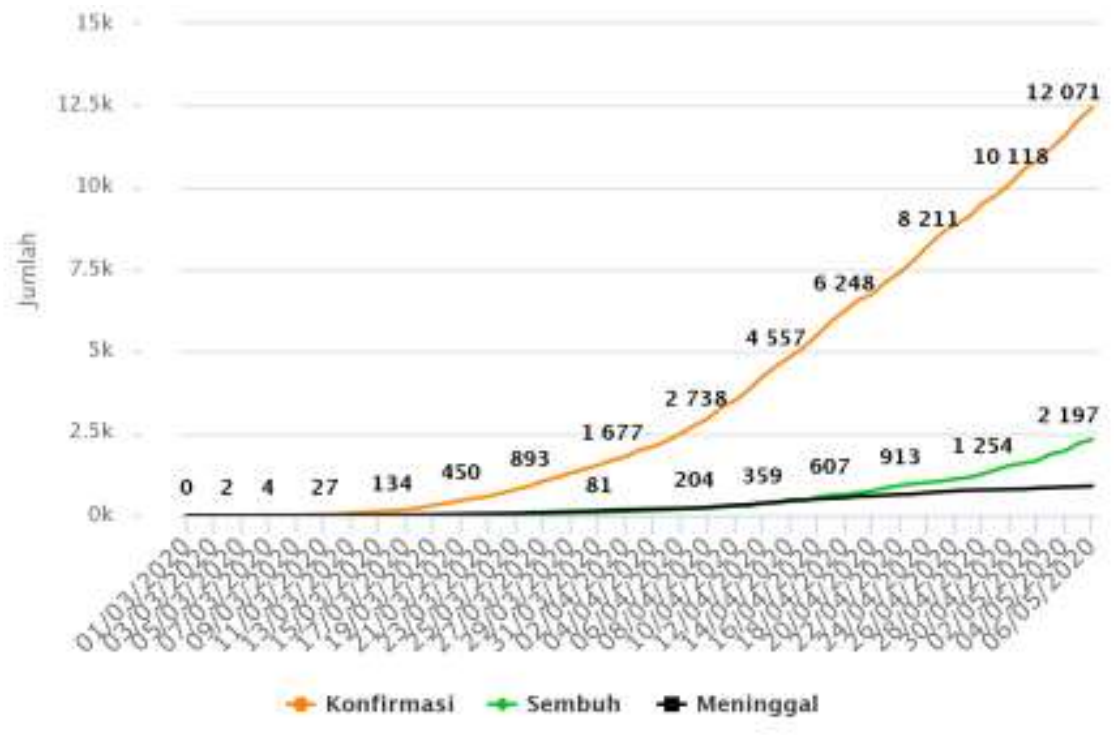

[2] May 6, 2020, 16.00

It must be realized that the addition of positive cases, once again still illustrates that there are still positive cases that have not been isolated, there is still transmission due to close contact, no one has been diligent in washing hands with soap. The public must be disciplined in implementing various policies that have been issued by the government in order to break the chain of transmission of Covid-19 including by staying at home, keeping a minimum physical distance of 1 meter, and washing hands with soap. The Indonesian Ministry of Health's policies are applied 
to healthy people, people with monitoring (ODP), people without symptoms (OTG), patients with supervision (PDP), Covid-19 patients, and vulnerable groups [3].

\section{Impact on Student Education}

This virus spreads through individuals to other individuals (through touch, saliva, etc.), so many countries around the world simultaneously ask their people to apply social distance, even physical distance to inhibit the growth of COVID 19. This has also inhibited educational activities that exist throughout the world. Not only were the activities of educational institutions even to the world of business, the world of tourism, and health affected. Most governments around the world have temporarily closed educational institutions in an effort to curb the spread of the COVID-19 pandemic. This national closure has an impact on more than $91 \%$ of the world's student population. Several other countries have implemented local closures which have an impact on millions of additional students [4]. UNESCO supports countries in their efforts to reduce the direct impact of school closures, especially for the more vulnerable and disadvantaged communities, and to facilitate the continuation of education for all through distance learning [5]

In the United States, the country with the highest confirmed COVID-19 infection, the national social long distance protocol has been implemented by the President. For the first time in a hundred years since the 1918 flu pandemic, the US population was mandated to live in their households and avoid public contact. As a result, the majority of public places and services have ceased operations. Following the closing of the University of Washington on March 7, further than a thousand colleges and universities in the United States had canceled class and campus activities directly, which impacted millions of students [4].

Since the outbreak of a pandemic caused by the Corona virus in Indonesia, many ways have been taken by the government to prevent its spread. One of them is through a circular of the Ministry of Education and Culture (Kemendikbud) of the Directorate of Higher Education No. 1 of 2020 about preventing the spread of Corona Virus Disease (Covid-19) in tertiary institutions. Through this circular the Ministry of Education and Culture gave instructions to universities to conduct distance learning and advised students to learn from their respective homes. There are at least 65 universities in Indonesia that provide learning from home to prevent the spread of Covid-19 (CNN Indonesia, 2020).

In an effort to prevent the spread of Covid-19, WHO recommends stopping activities that have the potential to cause mass crowds. For this reason, conventional learning that gathers many students in one room needs to be reviewed for implementation. Learning must be carried out with scenarios that are able to minimize physical contact between students and other students, or between students and lecturers. One alternative form of learning that can be carried out during the Covid-19 emergency is online learning. According to Moore, Dickson-Deane, \& Galyen (2011) Online learning is learning that uses internet networks with accessibility, connectivity, flexibility, and the ability to bring up various types of learning interactions [6].

In an effort to uphold the Student Learning Activity (SLA) in the midst of the COVID-19 Pandemic, the Ministry of Education and Culture has arranged policies through Circular Letter No. 4 of 2020 Ministry of Education in which four matters are discussed. The first is online 
learning, both interactively and non-interactively. This needs to be done even though not all children can do that because of infrastructure. In this case the most important thing is learning must occur even at home. Without teachers the target must be that the curriculum must be achieved. Not move the school at home, but choose essential materials that children need to do at home. Then secondly, the teaching staff or teacher must provide education to children about life skills, namely education that is contextual in accordance with the conditions of each home, especially the understanding of COVID-19, regarding the characteristics, how to avoid it and how to prevent someone from contracting. Furthermore, the third, learning at home must be adjusted to the interests and conditions of each child. The fourth is for teachers or teachers, the tasks given to students do not have to be assessed as usual in school, but rather qualitative assessments that are motivating to children. There are several learning groups held at schools during the COVID-19 pandemic, namely schools that conduct distance learning in full and utilize a variety of online education platforms, schools that are still implementing semi daring, where assignments are sent via message application and there is no direct interaction, and who do not have internet access, electricity, or television [7].

Impact on Students

Covid-2019 is pneumonia that arose on December 31, 2019 in Wuhan, China, and then swept the world. The continuing spread of the epidemic, strict isolation measures and delays in starting schools, colleges, and universities throughout the country are expected to affect the mental health of students. There have been reports of the psychological impact of the epidemic on the general public, patients, medical staff, children, and older adults [8] - [11].

About $24.9 \%$ of students have experienced anxiety because of this COVID-19 outbreak. Living in urban areas, living with parents, having a stable family income are protective factors for students against the anxiety experienced during the COVID-19 outbreak. However, having a relative or acquaintance who is infected with COVID-19 is an independent risk factor for anxiety experienced. COVID-19 stressors namely economic stressors, effects on daily life, and academic delays are positively related to anxiety levels of Chinese students during epidemics, while social support is negatively correlated with their anxiety [10].

Students' mental health is greatly affected when faced with a public health emergency, and they need attention, assistance, and support from the community, family, and tertiary institutions. It is recommended that the government and schools should collaborate to solve this problem in order to provide crisis-oriented psychological services that are of high quality and timely bad character to students [12].

People start a new life in quarantine to be safe. Quarantine life is accompanied by psychological, social and economic consequences, and its implementation requires the support, supervision and compliance of the country's medical staff. Research conducted to postgraduate students with natural experience of living in quarantine. The research data reached theoretical saturation with 15 interviews. All data is recorded and handwritten and analyzed using the "Van Manen Phenomenology" approach. Data analysis includes four main themes, "developing negative emotions, confusion and pessimism", "Developing obsessive-compulsive behavior about the 
body and washing", "concerns about family health", "economic and social care, fear tomorrow will get rid of the virus". Students living in quarantine are very unique Understanding the complexity of their experiences, beliefs, and attitudes about living in quarantine can provide comprehensive plans for decision makers, health care professionals, and mental health professionals [12].

\section{Impact on Student Mental Health Problems}

The COVID-19 pandemic is a non-natural disaster that can have an impact on the mental health and psychosocial conditions of everyone. According to WHO (2020), the emergence of a pandemic caused stress to various levels of society. Although so far there has not been a systematic review of the effects of COVID-19 on mental health, a number of studies related to pandemics (including bird flu and SARS) have shown a negative impact on the mental health of sufferers [8], [11].

Research conducted in mainland China aims to explore the cognition, psychological state, anxiety and depression level of students during the 2019 coronavirus epidemic (COVID-19), so as to understand the psychological dynamics of students. 509 students were collected with an internet questionnaire. The Self-Assessment Anxiety Scale and the Depression Scale Epidemiological studies are used to value each anxiety and depression symptom. Findings During the COVID-19 epidemic, the majority of students strongly agreed to reduce going out and gathering. There were statistical differences between the different sexes of students in anxiety and panic risk exposure. Moreover, his anxiety and depression levels of students in China during the COVID-19 epidemic were higher than the level of the national Norm. In addition, logistic regression analysis shows that the panic situation is epidemic. During the COVID-19 epidemic, student anxiety and depression levels increased significantly, which was also related to many factors. Therefore, it is very important to conduct psychological interventions that are needed on students [8].

\section{Student Coping Strategies}

Because of the rapid spread of COVID-19, strong transmission, death in severe cases, and no specific drugs, it poses a major threat to human life and health, and also has a large impact on the mental health of the general public, causing people with different levels of problems emotional. So we can predict that the outbreak of COVID-19 will cause public psychological reactions such as tension, anxiety, and fear that will cause psychological disorders such as acute stress disorder, post-traumatic stress disorder, depression and suicide [9].

COVID-19 is a major threat to the lives and health of nurses and has a large impact on their emotional responses and coping strategies. The study conducted an online questionnaire survey from February 1 to 9, 2020 to investigate the current state of emotional responses and strategies to deal with nurses and nursing students in Anhui Province. This study uses the COPE Brief modification method (Carver, 1997) and emotional response scale. The results found that women showed more anxiety and fear than men. Participants from the city showed more anxiety and fear than participants from the countryside, but rural participants showed more sadness than the urban participants. The closer COVID-19 is to the participants, the stronger anxiety and anger. 
Compared with nursing students, nurses have stronger emotional responses and are more willing to use coping that focuses on problems. People may have a cycle of "the more fear, the more focus on the problem". And people might "The angrier, the more coping that focuses on emotions", "the coping that is more focused on the problem, the more anxious, angrier, and more sadness." COVID-19 is a source of pressure with great influence, both for individuals and for public social groups. Different individuals and groups may experience varying degrees of psychological crisis, and the nurses who are the core of the incident are affected. The hospital must focus on providing psychological support to nurses and providing psychological assistance and timely training in coping strategies Improve the nurse's ability to manage emotions and effective coping strategies, providing strong guarantees to firmly win the battle against epidemic prevention and control [10].

\section{Impact on Information}

In the midst of a situation that makes people uneasy and sad, hoax news circulates about the Corona virus on social media. Based on the results of research conducted concluded that during January-March 2020, hoax news has been spread about Corona Virus 50 times, with the topic of contracting Corona Virus, treatment and prevention of Corona Virus infection, and social behavior in dealing with the virus, Website https: //www.kominfo.go.id/, is the site that provides the most warning to the public about the Corona Virus hoax, while DKI Jakarta is the most mentioned area in hoax reporting, and the most widely disseminated hoax news on March 24, 2020 is 10 times [13].

Students tend to focus their discussions on topics very close to their neighborhood, such as school closing and local news. Although the positive percentage of COVID-19 Tweets was very low for both demographics, college students proved to be significantly more negative. In addition, positive microscopic examinations and negative tweets reveal their very problematic feelings in the midst of the spread of COVID-19, as well as adverse reactions to disturbances in their lives such as aggression charged by racism. In addition, we found a change in the target of racism during COVID-19 towards the East Asian community, which most students and the general public opposed. Analysis on fine-grained linguistic information, such as emotions, hate speech, and racism detection can be carried out to gain further insight into more specific COVID-19 related problems detailed in our study [11]

\section{REFERENCES}

[1] “coronavirus-disease-2019." [Online]. Available: https://www.who.int/emergencies/diseases/novel-coronavirus-2019. [Accessed: 06-May2020].

[2] "pemantauan-covid-19-kementerian-kesehatan-republik-indonesia." [Online]. Available: http://pusatkrisis.kemkes.go.id/covid-19-id/. [Accessed: 06-May-2020].

[3] "kementerian-kesehatan-republik-indonesia." [Online]. Available: https://www.kemkes.go.id/article/view/20043000003/pedoman-dukungan-kesehatan-jiwadan-psikososial-pada-pandemi-covid-19.html\%0A\%0A. [Accessed: 06-May-2020]. 
[4] M. Billy, "The Influence of Dynamic Organizations and the Application of Digital Innovations to Educational Institutions in the World during the COVID-," 2019.

[5] "school-closures-caused-by-coronavirus-(covid-19)." [Online]. Available: https://en.unesco.org/covid19/educationresponse. [Accessed: 06-May-2020].

[6] S. R. Rahman, "Pembelajaran Online di Tengah Pandemi Covid-19," vol. 02, no. 02, pp. 81-89, 2020.

[7] "Hardiknas Belajar dari COVID-19 dan Strategi Kemendikbud Tegakkan KBM - Berita Terkini | Gugus Tugas Percepatan Penanganan COVID-19." [Online]. Available: covid19.go.id/p/berita/hardiknas-belajar-dari-covid-19-dan-strategi-kemendikbudtegakkan-kbm. [Accessed: 06-May-2020].

[8] W. Cao, Z. Fang, G. Hou, M. Han, X. Xu, and J. Dong, "The psychological impact of the COVID-19 epidemic on college students in China," Psychiatry Res., vol. 287, no. March, p. 112934, 2020.

[9] X. Zhong, X. Liu, X. Liu, J. Liu, and X. Zhong, "The Lancet Global Health Psychological state of college students during COVID-19 epidemic Psychological state of college students during COVID-19 epidemic Summary."

[10] L. Huang, F. Xu, and H. Liu, "Emotional responses and coping strategies of nurses and nursing college students during COVID-19 outbreak," 2020.

[11] V. Duong, J. Luo, and Y. Wang, "The Ivory Tower Lost : How College Students Respond Differently than the General Public to the COVID-19 Pandemic," 2019.

[12] A. Khodabakhshi-koolaee, "Living in Home Quarantine : Analyzing Psychological

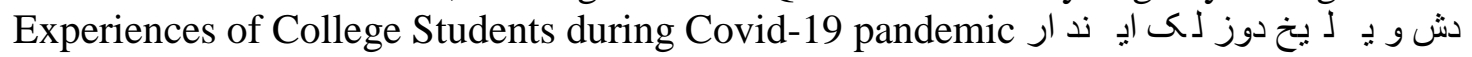

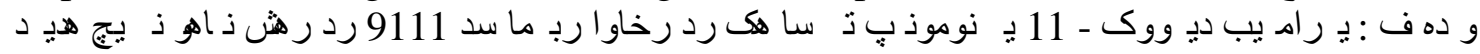

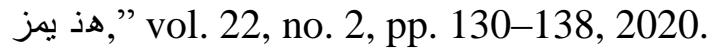

[13] N. R. Rahayu and Sensusiyati, "ANALISIS BERITA HOAX COVID - 19 DI MEDIA SOSIAL DI,” vol. 01, no. 09, pp. 60-73, 2020.

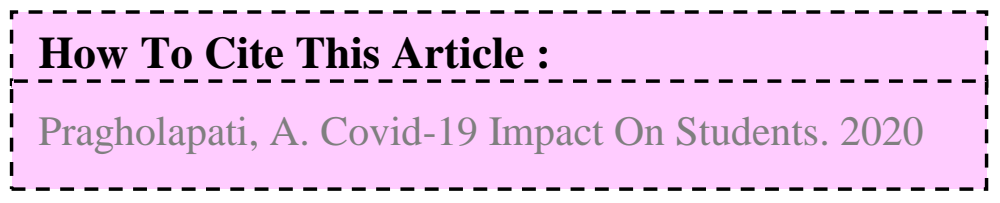

